\title{
The investigation of antibiotic resistance and rapid detection of group B Streptococcus (Bca) from vaginal specimens of pregnant women by colony PCR method
}

\author{
Aazam Khani Daramroodi ${ }^{1}$, Fatemeh Keshavarzi ${ }^{2 *}$, Farshid Raissi ${ }^{3}$
}

1. Department of Biology, Kurdistan Science and Research Branch, Islamic Azad University, Sanandaj, Iran

2. Department of Genetics, Sanandaj Branch, Islamic Azad University, Sanandaj, Iran

3. Department of Pathology, Faculty of Medicine, Kermanshah University of Medical Science, Kermanshah, Iran

*Corresponding author:Tel: +98 8733287652 Fax: +98 8733233831

Address: Department of Genetics, Sanandaj Branch, Islamic Azad University, Sanandaj, Iran

E-mail: fkeshavarzi@iausdj.ac.ir

Received; 2017/12/15 revised; 2018/01/1 accepted; 2018/01/15

\section{Abstract}

Introduction: Group B Streptococcus (GBS) is one of the most causes of neonatal infections. The bacterium colonizes genitourinary tracts of pregnant women and transmits to infants. The aim of this study was investigating colony PCR and culture methods to detection of GBS in pregnant women.

Materials and methods: Hundred pregnant women, at the $35^{\text {th }}$ and $37^{\text {th }}$ weeks of pregnancy, were selected from the Obstetrics and Gynecology Unit of the Moatazedi and Shahid Chamran Hospitals in Kermanshah province. Specimens were collected from vaginal introitus and investigated by selective culture and colony PCR methods. Then, antibiotic resistance tests were performed according to the latest guidelines of Clinical and Laboratory Standards Institute (CLSI).

Results: Prevalence of GBS colonization was shown to be $5 \%$ and $6 \%$ by the culture and colony PCR methods, respectively. Also, resistance rate to erythromycin, penicillin, vancomycin, and the clindamycin were determined to be 50\%, 16.66\%, 16.66\% and $33.33 \%$, respectively. Moreover, the highest resistance was for erythromycin and the appropriate antibiotics were penicillin and then vancomycin.

Conclusion: A higher prevalence of GBS colonization in pregnant women in the Kermanshah city of Iran was detected using colony PCR method compared to culture method.

Keywords: Antibiotic Resistance, BCA gene, Colony-PCR, GBS

\section{Introduction}

Streptococci are spherical and grampositive bacteria, which are the natural flora of the pharynx, skin, and intestines of humans, and if they enter the blood or tissues, cause disease (1). Streptococcus agalactia ( $S$. agalactia), the second group of streptococcal bacteria was recognized as a cause of breast infection in cows since 1970 (2). They are similar to other streptococci in terms of morphology and metabolism. But, they create larger colonies and narrow zone of betahemolysis in culture media. Some of them are non-hemolytic or have alpha-hemolytic

Copyright (C) 2018 Journal of Basic Research in Medical Science. This is an open access article distributed under the terms of the Creative Commons Attribution 4.0 International License (https://creativecommons.org/licenses/by/4.0/) which permits copy and redistribute the material, in any medium or format, provided the original work is properly cited. 
strains (3). A specific polysaccharide antigen, composed of rhamnose, n-acetyl Glucosamine and galactose, is in their cell wall. $S$. agalactia is a pathogenic bacterium that causes diseases such as bacteremia, meningitis and early death in newborn. S. agalactica also prominent veterinary pathogens because they are can cause mastitis disease in cows (breast inflammation in dairy cows). Bca gene encodes alpha-C protein. The removal of the gene (bca) causes to reduce the pathogenicity of GBS in the immature mouse model (4-7). The previous investigation demonstrates that $10-40 \%$ of pregnant women have a bacterium colonized and $70-80 \%$ of those bacteria transmitted to infants that are colonization and subsequent diseases in the infant which could occur in the uterus at birth or in the first months of life. The incidence of this disease in the 1990s has been significantly reduced due to the use of antibiotics during childbirth (3). A number of $S$. agalactia has been resistant at least in one of the antibiotics erythromycin, penicillin, vancomycin, and clindamycin (4). Risk factors included prolonged rupture of the embryonic curtain (less than 18 hours), preterm delivery (less than 37 weeks), maternal fever during childbirth (more than 38 degrees), urinary tract infection during pregnancy, history of the complications of GBS infections. In the screening program, GBS culture from a vagina and rectum occur at 35-37 weeks of Pregnancy (5). While, in developed countries, in pregnant women sepsis is one of the causes of death in infants $(6-8)$. The bacterium in vaginal or rectum colonize of the pregnant women in Southeast Asia is estimated and shows about 20-30\% (9-12), In the United States, the Center of Disease Control (CDC) states that pregnant women of 35-37 weeks are screened to identify the bacterium carriers (13) which are treated by antibiotic prophylaxis. In fact, a recognizing and diagnosis, effective drug against this bacterium is important in protecting the health of pregnant women (15-14). Carrier diagnostic methods of this bacterium are different. Therefore, the aim of the present study was screening for GBS colonization of pregnant women by culture and Colony-PCR methods for BCA gene.

\section{Materials and methods}

Samples: Vaginal secretion samples were collected from 100 pregnant women during visits to the Obstetrics and Gynecology Unit of the Moatazedi and ShahidChamran Hospitals in Kermanshah Province. Samples were collected using sterile swabs without using a speculum, according to CDC guidelines, during physical examination of the women between the $35^{\text {th }}$ and $37^{\text {th }}$ weeks of pregnancy. All patients provided written informed consent prior to inclusion in the study.

GBS culture: the swabs were transferred to Todd-Hewith-Broth medium and incubated at $33-37^{\circ} \mathrm{C}$ for 18 to $24 \mathrm{~h}$. Then, Samples were cultured on 5\% sheep blood agar plates and incubated at $33-37^{\circ} \mathrm{C}$ for 18 to $24 \mathrm{~h}$ in a $5 \% \mathrm{CO}_{2}$ atmosphere. $\beta$ hemolytic and non- $\beta$-hemolytic colonies were subculture in Todd-Hewitt broth and subjected to CAMP (creating a flash head at the intersection of Staph and Strep bacteria) test and latex agglutination analyses to confirm that they were GBS.

Antibiogram tests: Antibiotic resistance was evaluated using a diffusion method according to the standard CLSI instructions and the use of the antibiotic discs of erythromycin, penicillin, vancomycin, and clindamycin, and concentration, resistance, and sensitivity of these antibiotics were determined.

Colony PCR assay: In this study, a specific fragment of the BCA Streptococcus gene of B group was proliferated at 205 bp. The colony PCR was performed to a volume of $25 \mu \mathrm{L}$ containing $1.5 \mathrm{U}$ of Taq DNA polymerase (sinagene,Iran); $0.4 \mu \mathrm{M}$ each GBS-specific primers bca $\mathrm{F}\left(5^{\prime}\right.$ GCAACTGAGAAACATCCCCA-3') and 
bca $\mathrm{R}$ (5'- GCTGCATCTACAA TTCCAGGG $\left.-3^{\prime}\right) ; 2.5 \mu \mathrm{L}$ of $10 \times$ buffer containing $15 \mathrm{mM} \mathrm{MgCl} 2 ; 2.5 \mu \mathrm{L}$ of dNTP with $0.2 \mathrm{mM}$ each nucleotide; and some bacterial colonies. The conditions for the PCR were as follows: $94^{\circ} \mathrm{C}$ for $1 \mathrm{~min}$, followed by 35 cycles divided into denaturation $\left(94^{\circ} \mathrm{C}, 1 \mathrm{~min}\right)$, annealing $\left(55^{\circ} \mathrm{C}, 45 \mathrm{sec}\right)$, and extension $\left(72^{\circ} \mathrm{C}, 1\right.$ min). Subsequently, the material was maintained at $72^{\circ} \mathrm{C}$ for $10 \mathrm{~min}$, and the amplified product was stored at $4{ }^{\circ} \mathrm{C}$ until analysis. The electrophoresis was performed using $1.5 \%$ agarose gel. The amplification products were detected using under ultraviolet light. A ladder with fragments of known molecular weight was used as a marker (100pb ladder).

\section{Results}

Of all specimens, colony-PCR analysis detected GBS in a higher number of patient samples $(6 \%)$ than the culture method (5\%) (Table 1).

Table 1. Prevalence of Group B Streptococcus (GBS) colonization in 100 pregnant women, as determined by culture and PCR-based detection methods.

\begin{tabular}{lccc}
\hline & \multicolumn{3}{c}{ Colonization* } \\
\hline \multirow{3}{*}{ Method } & Positive & Negative & Samples \\
\cline { 2 - 4 } Culture & Number (\%) & Number (\%) & Number \\
Colony PCR & $5(5)$ & $95(95)$ & 100 \\
\hline
\end{tabular}

As all the culture-positive samples were also positive by the PCR analysis, the sensitivity and specificity of the applied colony PCR method was $100 \%$ and $95.6 \%$, respectively. Of the 95 culture-negative specimens, one tested positive for GBS by colony PCR.

Also, the results of antibiotic resistance test showed that resistance to erythromycin, penicillin, vancomycin and clindamycin were determined as $50 \%$, $16.66 \%, \quad 16.66 \%$ and $33.33 \%$, respectively. In addition, the highest resistance was against erythromycin and the appropriate antibiotics were penicillin and then vancomycin (Table 2). Based on the results of 6 known isolates from $S$. agalactia, some of them showed resistance to at least one of the antibiotics erythromycin, penicillin, vancomycin, and clindamycin. The isolates showed more sensitivity to vancomycin. Data analysis also showed that some of the isolates were resistant to two antibiotics at the same time. Resistance to erythromycin and clindamycin shown to be increased.

Table 1. Frequency and percentage of resistance and sensitivity measured from 6 isolates of $S$. agalactia.

\begin{tabular}{lccc}
\hline & \multicolumn{3}{c}{ Resistance and sensitivity rates } \\
\cline { 2 - 4 } Antibiotic & Sensitive & Medium & Resistance \\
\hline Erythromycin & $2(33.33)$ & $1(16.66)$ & $3(50)$ \\
Penicillin & $3(50)$ & $2(33.33)$ & $1(16.66)$ \\
Vancomycin & $5(83.33)$ & $0(0)$ & $1(16.66)$ \\
Clindamycin & $4(66.33)$ & $0(0)$ & $2(33.33)$ \\
\hline
\end{tabular}

Data are shown as number (percent).

\section{Discussions}

Detection of GBS colonization during pregnancy and prenatal care recommend by Medical Guidelines. In other countries, for example, European countries, such guidelines have been used for more decades (15-14). GBS that colonizes and infect the genital and urinary tract are causes of GBS neonatal disease. Therefore, this study and previous studies can help to set out guidelines for the prevalence indexes for GBS, according to geographic location, sociodemographic and clinical characteristics in different rejoin of Iran. Prevalence of GBS colonization was $5 \%$ and $6 \%$ by the culture and colony PCR methods, respectively. In this study, the GBS isolation rates increased to $6 \%$ when used by the colony PCR method. Sampling should be from vaginal and perianal, but only used vaginal swabbing. Also, in this study the results of antibiogram test showed resistance rates to erythromycin, penicillin, vancomycin and clindamycin were determined as $50 \%, 16.66 \%, 16.66 \%$ and $33.33 \%$, respectively. In addition, the highest resistance was to erythromycin and the appropriate antibiotic was first 
evaluated for penicillin and then vancomycin. The results indicate that resistance to erythromycin and penicillin and other antibiotics are increasing. Widespread use of antibiotics to prevent infections caused by this bacterium has raised concerns about the appearance of microbial resistance in group B streptococci. The most commonly used antibiotics are penicillin (14-17). In cases of allergy to beta-lactam, erythromycin and clindamycin are replaced; if clindamycin is susceptible or unavailable, vancomycin is used (15). Resistance to any of these drugs has been reported in numerous studies from around the world. S. agalactia, as an opportunistic organism, is able to produce various infections of all ages. This bacterium tends to be colonized in pregnant women and can be caused preterm delivery as well as infections dangerous (including meningitis, pneumonia, and septicemia) (14). Approximately 40 to 10 percent of pregnant women with GBS bacteria in both the rectum and the vagina carrying bacteria is colonized, and 80-70 percent of these women transmit GBS to their infants; therefore, the occurrence of carriers groups B streptococcus in pregnant women can be considered as a serious risk factor for pregnancy (16). According to the CDC proposal, all pregnant women between 37-35 weeks of pregnancy should be considered for the being carrier of GBS and treated with antibiotics (17). In the other study on 605 samples, they were obtained 16 percent in a culture method and a 28 percent in colony-PCR method on GBS vector (18). Also, in another study conducted in Iran, the GBS carriers in 250 pregnant women, 8.4 percent in culture, and molecular methods of 6.9 percent were reported (19).

\section{References}

1. Bidgani SA, Navidifar TA, Najafian MB, Amin MA. Comparison of group $\mathrm{B}$ streptococci colonization in vaginal and rectal specimens by culture
For study the resistance level of group B resistance, the frequency of the bca gene was reported to be 5.1 percent was reported (20). The results of this study are closed to the results above. In a study done in Brazil by Costa, the antibiotic resistance of group B streptococci, clindamycin, 25.4 and erythromycin 23.4 percent was reported (10). Also, Shahram Habibzadeh et al (2009) performed a study on the antibiotic resistance of group B streptococci, the erythromycin resistance of 1.6 and clindamycin 17 percent reported (20). In another study, the antibiotic resistance of group B streptococci to erythromycin and clindamycin, 15.57 and 92.2 percent respectively was reported (21).The results of isolated strains on this study were matched with some of the above and were not match with some another ones. This may be due to the difference in the exposure of bacteria to the antibiotics used for other purposes. Although, the suitable use of antibiotics leads to rapid treatment of streptococcal infections, inappropriate administration and change of bacterial properties lead to the drug resistance in this bacterium.

\section{Conclusion}

Based on the results, the rate of GBS prevalence in Kermanshah women is increasing. In addition, a higher prevalence of GBS colonization in pregnant women in Kermanshah was detected using the colony PCR method.

\section{Acknowledgments}

The authors are grateful to laboratory staff of Obstetrics and Gynecology Unit of the Moatazedi and ShahidChamran Hospitals in Kermanshah.

method and polymerase chain reaction technique. J Chin Med Assoc. 2016; 79(3):141-5. 
2. Verani JR, McGee L, Schrag SJ; Division of Bacterial Diseases, National Center for Immunization and Respiratory Diseases, Centers for Disease Control and Prevention (CDC). Prevention of Perinatal Group B Streptococcal Disease: revised guidelines from CDC, 2010. MMWR Recomm Rep. 2010; 59(RR-10):1-36.

3. Sibbald MJ. Mapping the pathways to staphylococcal pathogenesis by comparative secretomics. Microbiol Mol Biol Rev. 2006;70(3):755-88.

4. Kocoglu E, Karabay O, Yilmaz F, Ekerbicer $\mathrm{H}$. The impact of incubating the throat culture for $72 \mathrm{~h}$ on the diagnosis of group A beta-hemolytic streptococci. Auris Nasus Larynx. 2006;33(3):311-3.

5. Bakhtiari R, Soltan Dallal M, Zaemi Yazdi J, Fallah J, Amir Mozaffari N, Pourmand M, et al . Evaluation of PCR method for diagnosis of Group B Streptococcuscarriage in pregnant women. Iran J Med Microbiol. 2007; $1(2): 1-8$.

6. Barcaite E, Bartusevicius A, Tameliene R, Kliucinskas M, Maleckiene L, Nadisauskiene R. Prevalence of maternal group B streptococcal colonization in European countries. Acta Obstet Gynecol Scand. 2008;87(3):260-71.

7. Khan MA, Faiz A, Ashshi AM. Maternal colonization of group B streptococcus: prevalence, associated factors and antimicrobial resistance. Ann Saudi Med. 2015;35(6):423-7.

8. Ciraj AM. Clindamycin resistance among clinical isolates of staphylococci. Ind J Pathol Microbiol. 2009; 52(1): 49-51.

9. Nomura ML, Passini Júnior JR, Oliveira UM. Selective versus nonselective culture medium for group B Streptococcus detection in pregnancies complicated by preterm labor or preterm-premature rupture of membranes. Braz J Infect Dis. 2006; 10(4):247-50.
10. Costa NDVL, Carvalho M, Pone SM, $\mathrm{G}$ Júnior SC. Gestantes colonizadas pelo Streptococcus do grupo B e seus recém-nascidos: análise crítica da conduta adotada no Instituto Fernandes Figueira, Fundação Oswaldo Cruz. Rev Paul Pediatr. 2010;28(2):155-61.

11. Rocchetti TT, Marconi C, Rall VLM, Borges VTM, Corrente JE, da Silva MG. Group B streptococci colonization in pregnant women: risk factors and evaluation of the vaginal flora. Arch Gynecol Obstet. 2011; 283(4):717-21.

12. De-Paris F, Machado ABMP, Gneno TC, Ascoli BM, Oliveira KRP, Barth AL. Group B Streptococcus detection: comparison of PCR assay and culture as a screening method for pregnant women. Braz J Infect Dis. 2011;15(4):323-7.

13. Castellano-Filho DS, Silva VL, Nascimento TC, Vieira MT, Diniz CG. Detection of Group B Streptococcus in Brazilian pregnant women and antimicrobial susceptibility patterns. Braz J Microbiol. 2010;41(4):1047-55.

14. Díaz TM, Nieves BM. Comparison between culture media and procedures to detect Streptococcus agalactiae in pregnant women. Rev Chil Infectol. 2008;25(2):108-13.

15. Larcher JS, Capellino F, De Giusto R, Travella C, Balangione FG, Kreiker G, et al. Group B Streptococcus colonization during pregnancy and prevention of early onset of disease. Medicina (B Aires). 2005;65(3):201-6.

16. Bidgani SA, Navidifar TA, Najafian $\mathrm{MB}$, Amin MA. Comparison of group B streptococci colonization in vaginal and rectal specimens by culture method and polymerase chain reaction technique. J Chin Med Assoc. 2016;79(3):141-5.

17. Quinlan JD, Hill DA, Maxwell BD, Boone S, Hoover F, Lense JJ. The necessity of both anorectal and vaginal cultures for group B Streptococcus 
screening during pregnancy. J Fam Pract. 2000;49(5):447-8.

18. Clarke C, O'Connor L, Carré-Skinner H, Piepenburg O, Smith TJ. Development and performance evaluation of a recombinase polymerase amplification assay for the rapid detection of group $B$ streptococcus. BMC Microbiol. 2016;16(1):221.

19. Mousavi SM, Hosseini SM, Mashouf RY, Arabestani MR. Identification of Group B Streptococci Using 16S rRNA, cfb, scpB, and atr Genes in
Pregnant Women by PCR. Acta Med Iran. 2016;54(12):765-70.

20. Habibzadeh S, Arzanlou M, Jannati E, Asmar M, Azari M, Fardiazar Z. [Maternal carriage of group $B$ Streptococcus in Ardabil, prevalence and antimicrobial resistance]. J Ardabil Univ Med Sci. 2010; 10 (1):14-20. (Persian)

Khoshkhoutabar, T, Zand, S, Abtahi, H., Rafiei, M. [Frequency and drug resistance of group B streptococcus in pregnant women in Markazi province, Iran]. mljgoums. 2015; 8 (4):75-80. (Persian) 